\title{
THERMODYNAMIC REVIEW OF TRIGENERATION SYSTEMS FOR POWER, HEATING AND COOLING REQUIREMENTS
}

\author{
Krishna Mani Mishra*, and Onkar Singh \\ Mechanical Engg. Dept, Harcourt Butler Technical University, Kanpur (UP) India
}

\begin{abstract}
Changing climate conditions have been burdening the present civilization with excessive cooling and heating requirements, apart from the industrial requirements for these. Trigeneration refers to simultaneous power, heating and cooling from any system. The requirement of heating and cooling if met from the low grade energy available in conventional gas/steam combined cycle power plant offers potential solution to the endangering environment for meeting heating and cooling needs. Present paper deals with the thermodynamic review of trigeneration technology and aims at introspection into its state of study across the world.
\end{abstract}

\section{Introduction}

Global energy consumption has grown steeply since last many decades and is expected to increase by around $40 \%$ between $2006 \& 2030$ [1] [2009].In general the availability of energy in useable form depends upon the numerous renewable \& non- renewable sources of energy with varying lifecycle of their replenishment. The major portion of energy requirement is being met from the non-renewable sources of energy, i.e. fossil fuels which have very long life cycle of replenishment and the fast depletion of fossil fuel is becoming a cause of concern for sustainability in the future. Amongst various options for ensuring sustainability, the energy conservation, energy efficiency \& environmental concerns happen to be some of the key initiatives for meeting future energy challenges.

Combined cycle power plants are a consequence of initiatives for optional utilization of the energy sources in which gas turbine (GT) exhaust from topping cycle is used to run steam turbine (ST) based bottoming cycle through a heat recovery steam generator (HRSG). In view of increasing demand for cooling and heating along with power, it is worthwhile to explore efficient system, which can be combined cooling, heating \& power (CCHP) option, i.e. three different objectives being taken care of in a power plant for meeting the power \& heating/ cooling requirements of utilities with the help of single energy source. Such arrangements are also known as Trigeneration (TG) systems. In CCHP or trigeneration systems, the lost heat is utilized to generate a cold effect, in addition to power and heat.

The present paper aims at reviewing the present state of trigeneration technology starting from its evolution. The emergence and development of trigeneration systems for cooling, heating and power as reported in literature from time to time has been studied and compiled for creating a ready reckoner for those working in this field. Chronological developments in the trigeneration and related field have been suitably detailed in this paper.

\section{NOMENCLATURE}

APG - Absorption Power Generation HRSG - Heat Recovery Steam Generator

AWKRC - Ammonia Water Kalina Rankine cycle

ORC - Organic Rankine Cycle

CCHP - Combined Cooling, Heating, and Power

SOFC - Solid Oxide Fuel Cell

CHP - Combined Heating, and Power

ST - Steam Turbine

GHG - Greenhouse Gas

TG - Trigeneration

GT - Gas Turbine

TLC - Trilateral Cycle

\section{Evolution of CCHP around the world}

All over the world, the evolution of CCHP was categorized broadly into four main zones along with their: the US in 1978, Europe in 1970, Asia and the Pacific in 1980 and rest of the world in early 2000.Trigeneration made its impact in India in early 2000 [2] [2006].

The world is facing dramatic increase in greenhouse gas emissions. Russia, India and China were all ranked among the five largest emitters, with China taking the top spot. All things equal, the U.S. Energy Information Administration has indicated that the worldwide energy related $\mathrm{CO} 2$ emissions will increase to $46 \%$ by 2040 [3]. Therefore, finding more efficient energy systems is more crucial now than at any time since the beginning of the

Corresponding author: halkmmishra@gmail.com 

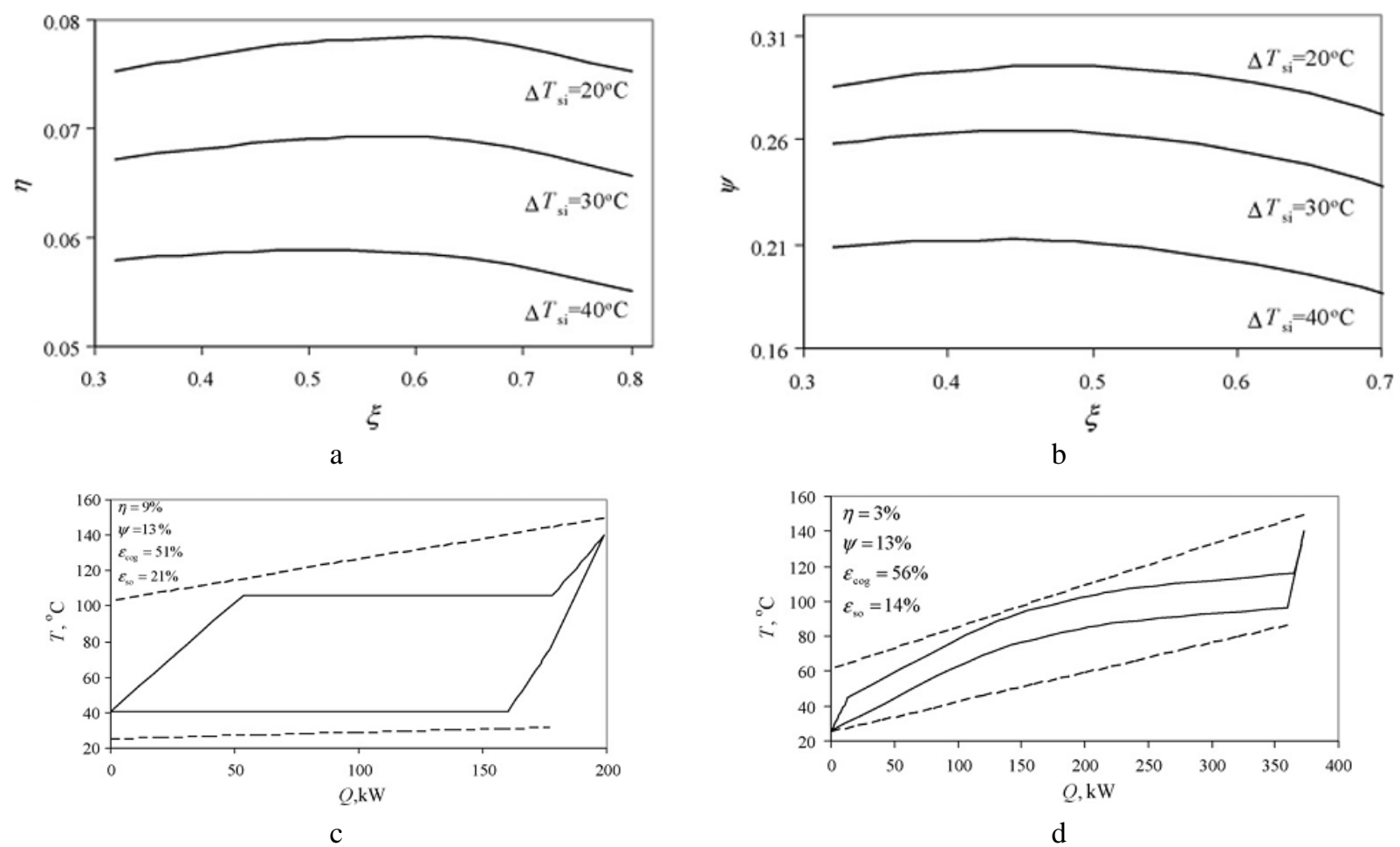

Fig. 1. The influence of the overall ammonia concentration on the cycle efficiency for a fixed $\eta_{\mathrm{E}}=0.7$ and three fixed values of the coolant temperature glide : (a) Energy efficiency, (b) exergy efficiency, (c): The Q-T diagram of the ORC with R21, (d) Kalina-type ammonia-water cycle

industrial revolution. The efficiency of conventional power plants that are based on single prime movers is usually less than $39 \%$. Thus, most of the energy is lost as waste heat. Integrating cooling and heating subsystems in a conventional plant could increase the plant efficiency significantly where the CHP efficiency could reach $80 \%$.In terms of electricity produced, theCHP accounted for more than $11 \%$ of the electricity produced in the G8 countries, as well as Brazil, China, India, Mexico, and South Africa in 2008. This percentage was expected to increase to $15 \%$ in 2015 and to $24 \%$ in 2030 . In other words, the electricity produced by CHP is expected to reach around $430 \mathrm{GWe}$ in 2015 and more than 830 GWe in 2030 [4] [2008].

The review of trigeneration plants can be carried out based on the thermodynamic cycle used, energy sources used, application, or analysis type. Significant contribution by some of the researchers in this area is discussed ahead in detail.

\subsection{Thermodynamics Cycle}

Calin Zamfirescu et al. [5] [2008] thermodynamically assess the performance of an ammonia-water Rankine cycle excluding boiler for power generation. This cycle has no pinch point and thus the exergy of the heat source can be better used by matching the temperature profiles of the hot and the working fluids in the benefit of performance improvement. The second feature comes from the use of the ammonia - water mixture to match the temperature profiles at the sink level. The influence of the expander efficiency, ammonia concentration and the coolant flow rate is investigated and reported for a case study. The optimized cycle is then compared to four organic Rankine cycles and a Kalina-type cycle and shows the best performance. It is also shown that, in order to determine the best cycle configuration and parameters, energy efficiency must be used only in conjunction with the amount of the heat recovered from the source. The efficiency of the cycle running with ammonia-water is 0.30 in contrast to steam-only case showing 0.23 exergy efficiency, which means an increment of $7.0 \%$ is obtained for the same operating conditions. The first results refer to the variation of the exergy and energy efficiencies with the overall ammonia concentration for a fixed value of the isentropic efficiency of the expander is 0.7 . These results are presented graphically in Fig. 1(a) and (b) for energy and exergy efficiency, respectively. For the ORC, based on critical temperature and pressure, four organic fluids are selected namely R141b (1,1-dichloro-1-fluoroethane), R123 (2,2-dichloro- 1,1,1-trifluoroethane), R245ca (1,1,2,2,3-pentafluoropropane), and R21 (dichlorofluoromethane). Fig 1 (c) shows ORC with R21 and Fig 1(d).shows the Kalina-type cycle. Fig 1(d).shows low energy efficiency, even though the exergy efficiency is the same as that of the ORC from Fig 1(c). The results of this comparative analysis are presented in Table 1.

Johann Fischer [6] [2011] compared and optimized trilateral cycle (TLC) systems with water as working fluid and optimized organic Rankine cycle (ORC) systems with pure organic working fluids. The study includes the heat transfer to and from the cycles. The TLC systems were optimized by the selection of the 
Table 1. Performance comparison among various cycles.

\begin{tabular}{|c|c|c|c|c|c|c|}
\hline \multirow[t]{2}{*}{ Parameter } & \multicolumn{4}{|c|}{ ORC cycles } & \multicolumn{2}{|c|}{$\mathrm{NH}_{3}-\mathrm{H}_{2} \mathrm{O}$ cycles } \\
\hline & R141b & R123 & R245ca & R21 & Kalina & TFC \\
\hline$\eta(\%)$ & 10 & 9 & 9 & 9 & 3 & 8 \\
\hline$\psi(\%)$ & 13 & 16 & 16 & 13 & 13 & 30 \\
\hline$\varepsilon_{\operatorname{cog}}(\%)$ & 27 & 36 & 40 & 51 & 56 & 71 \\
\hline$\dot{Q}_{s o}(\mathrm{~kW})$ & 132 & 179 & 189 & 198 & 373 & 477 \\
\hline$\dot{W}(\mathrm{~kW})$ & 13 & 17 & 18 & 18 & 13 & 38 \\
\hline$\varepsilon_{\mathrm{so}}(\%)$ & 15 & 19 & 20 & 21 & 14 & 43 \\
\hline$\varepsilon_{\mathrm{E}}(\%)$ & 34 & 43 & 45 & 57 & 76 & 93 \\
\hline$\dot{E}_{\mathrm{d}}(\mathrm{kW})$ & 19 & 26 & 28 & 31 & 60 & 42 \\
\hline$r_{\text {so }}(\%)$ & 34 & 36 & 36 & 36 & 62 & 23 \\
\hline$r_{\mathrm{si}}(\%)$ & 38 & 37 & 36 & 25 & 14 & 62 \\
\hline$r_{\mathrm{E}}(\%)$ & 27 & 27 & 27 & 38 & 24 & 15 \\
\hline
\end{tabular}

Table 2. Results for minimal heat capacity flow rate of the heat carrier at given heat carrier inlet temperature ,cooling agent inlet temperature and net power output.

\begin{tabular}{|c|c|c|c|c|c|c|c|c|c|c|}
\hline & Case I & & Case II & & Case E & & Cose IV & & Cose V & \\
\hline $\begin{array}{l}I_{3}(\mathbf{K}) \\
I_{3}(\mathbf{K})\end{array}$ & $\begin{array}{l}623.15 \\
33515\end{array}$ & & $\begin{array}{l}553.15 \\
33515\end{array}$ & & 55315 & & 403.15 & & 42315 & \\
\hline Cyde sype & nc & ORC- -2 & $\begin{array}{l}\mathrm{TlC} \\
\mathrm{nc}\end{array}$ & $\mathrm{OAC}-\mathrm{Q} 2$ & $\pi c$ & $\cos -\infty 2$ & $\mathrm{nc}$ & onc-s2 & $\mathrm{nc}$ & 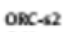 \\
\hline Werk fluid & water & $\mathrm{CC}_{2} \mathrm{H}_{10}$ & water & $\mathrm{CC}_{4} \mathrm{H}_{40}$ & waset & $\mathrm{CC}_{2} \mathrm{H}_{2 \mathrm{O}}$ & water & $=C_{0} \mathrm{H}_{10}$ & water & $\mathrm{C}_{\mathrm{y}} \mathrm{H}_{\mathrm{Z}}$ \\
\hline$T_{1}(\mathbf{K})$ & 35\&.15 & 358.15 & 358.15 & 358.15 & 311.15 & 311.15 & 311.15 & 311.15 & 312.15 & 311.15 \\
\hline$I_{2}(K)$ & - & 384.29 & - & 380.27 & - & 33765 & - & 321.54 & - & - \\
\hline$I_{2}(\mathrm{~K})$ & 59000 & 52900 & 53400 & 480.00 & 53400 & 47000 & 4900 & 443.60 & 41200 & 390.00 \\
\hline$I_{t}(\mathrm{~K})$ & 35\&.15 & 401.00 & 358.15 & 396.41 & 311.15 & 35709 & 311.15 & 333.55 & 312.15 & 314,03 \\
\hline$I_{s}(K)$ & - & 372.88 & - & 320.63 & - & 32296 & - & 324.55 & & - \\
\hline$p_{1}(\mathbf{R P a})$ & 57.87 & 288.8 & 57.87 & 288.8 & 6.633 & 68.88 & 6.633 & 3527 & 6633 & 1309 \\
\hline$p_{2}(\mathrm{RPa})$ & 10821 & 5412 & 4757 & 3342 & 4757 & 2546 & 1754 & 4706 & 350 & $\operatorname{son} 7$ \\
\hline$\nabla_{2}(1 / s)$ & 700 & 510 & 104 & 121.0 & 6.24 & 113.7 & 253 & 74.8 & 22.4 & 201.3 \\
\hline$Q_{e}(1 / \mathrm{s})$ & 4993 & 1778 & 6540 & 1937 & 33,546 & 4824 & 43,550 & 1711 & 69,896 & 997 \\
\hline$Q_{22}(\mathrm{BW})$ & - & 539 & - & 530 & - & 380 & - & 236 & - & - \\
\hline$x$ & 0.3739 & - & 0.2843 & - & 0.3184 & - & 0.2456 & - & 0.1561 & - \\
\hline ma & 0.1979 & 0.1863 & 0.1585 & 0.1727 & 0.2183 & a.2329 & 0.1706 & 0.1608 & 0.1136 & 0.10024 \\
\hline$I_{0}(K)$ & 370.53 & 394.29 & 369.15 & 408.70 & 32239 & 37289 & 321,42 & 333.18 & 32122 & 335.48 \\
\hline$I_{p}(\mathbf{x})$ & 416.16 & 394.29 & 306.57 & 483.42 & 38853 & 48000 & 321.42 & 368.16 & 32122 & 370.32 \\
\hline$\varepsilon_{66} \times(k W)$ & 5054 & 5368 & 6309 & 5700 & 4581 & 4294 & 5862 & 6217 & 8500 & 9766 \\
\hline$\varepsilon_{\operatorname{ac}}(\mathrm{KW} / \mathrm{K})$ & 2000 & 23.45 & 3420 & 40.08 & 1985 & 2382 & 36.14 & 38.86 & 86.33 & 111.4 \\
\hline$I_{2}(K)$ & 348.15 & 348,94 & 348.15 & 348,85 & 301.15 & 301.65 & 301.15 & 302.13 & 301.15 & 301.42 \\
\hline Qu(kW) & 4054 & 4363 & 5308 & 4790 & 3746 & 3309 & 4062 & 5217 & 7500 & 8766 \\
\hline$\varepsilon_{a}(\mathrm{~kW} / \mathrm{k})$ & 311.81 & 316.63 & 408.30 & 320.66 & 28815 & 245.15 & 37400 & 373.2 & 6000 & 660.6 \\
\hline $\mathrm{E}_{\mathrm{s}}(\mathrm{LW})$ & 2255 & 2644 & 2643 & 3016 & 1530 & 1836 & 1713 & 1950 & 2006 & 2705 \\
\hline$E_{g}(\mathrm{LW})$ & 198 & 320 & 330 & 796 & 37 & 249 & 61 & 124 & 152 & 391 \\
\hline$E_{p}(\mathbf{K W})$ & 1050 & 1096 & 1413 & 1210 & 0 & 0 & 0 & 0 & 0 & 0 \\
\hline$E_{*}(\mathrm{RW})$ & 1714 & 1784 & 2244 & 1964 & 82 & 75 & 106 & 99 & 171 & 196 \\
\hline 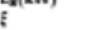 & 0.8732 & 0.8440 & 0.8812 & 0.8805 & a.7314 & a.7211 & 0.6813 & 0.6272 & 0.6312 & 0.5657 \\
\hline 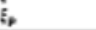 & 0.4435 & 0.3782 & 0.3784 & 0.3316 & 0.6536 & a.s447 & 0.5838 & 0.5128 & 0.477 & 0.3627 \\
\hline
\end{tabular}

maximum water temperature, the ORC systems by the selection of the working fluid and the process parameters. The optimization criterion is the exergy efficiency for power production being the ratio of the net power output to the incoming exergy flow of the heat carrier. Results will be presented for five different cases specified by the inlet temperature of the heat carrier and the inlet temperature of the cooling agent. The inlet temperature pairs are $\left(350^{\circ} \mathrm{C}, 62^{\circ} \mathrm{C}\right),\left(280^{\circ} \mathrm{C}, 62^{\circ} \mathrm{C}\right)$, $\left(280^{\circ} \mathrm{C}, 15^{\circ} \mathrm{C}\right),\left(220^{\circ} \mathrm{C}, 15^{\circ} \mathrm{C}\right)$ and $\left(150^{\circ} \mathrm{C}, 15^{\circ} \mathrm{C}\right)$. It is found that the exergy efficiency for power production is larger by $14 \%-29 \%$ for the TLC than for the ORC. On the other hand, the outgoing volume flows from the expander are larger for the TLC than for the ORC by a factor ranging from 2.8 for the first case to 70 for the last case. Fig 2 (a) shows the configuration of TLC System and Fig.2(b) and Fig 2(c) presents T-s and T-h diagram for TLC system respectively. Fig 2(d) shows T-h plot for ORC system respectively. Table 2 shows the results for minimal heat capacity flow rate of the heat carrier at given heat carrier inlet temperature ,cooling agent inlet temperature and net power output.
Pouria Ahmadi et al. [7] [2012] studied the performance of an integrated organic Rankine cycle for trigeneration. This trigeneration system consists of a gas turbine cycle, an organic Rankine cycle (ORC), a singleeffect absorption chiller and a domestic water heater. Energy and exergy analyses, environmental impact assessments and related parametric studies are carried out, and parameters that measure environmental impact and sustainability are evaluated. The exergy efficiency of the trigeneration system is found to be higher than that of typical combined heat and power systems or gas turbine cycles. The results also indicate that carbon dioxide emissions for the trigeneration system are less than for the aforementioned systems. The exergy results show that combustion chamber has the largest exergy destruction of the cycle components, due to the irreversible nature of its chemical reactions and the high temperature difference between the working fluid and flame temperature. The parametric investigations show that the compressor pressure ratio, the gas turbine inlet temperature and the gas turbine isentropic efficiency significantly affect the exergy efficiency and 


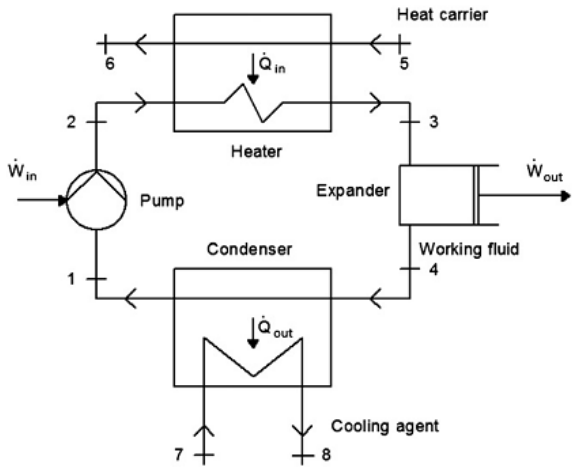

a

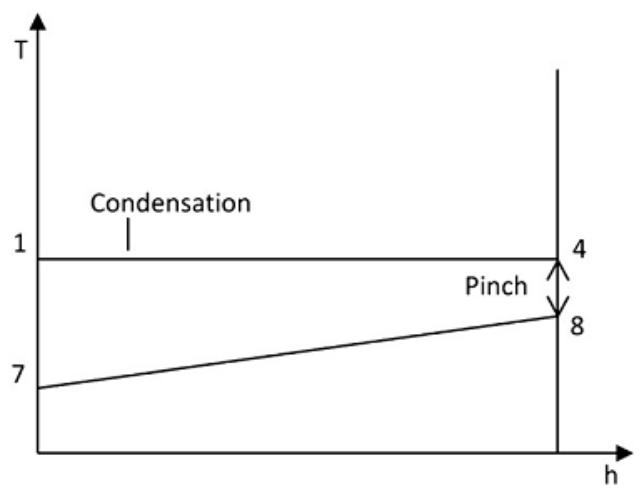

c

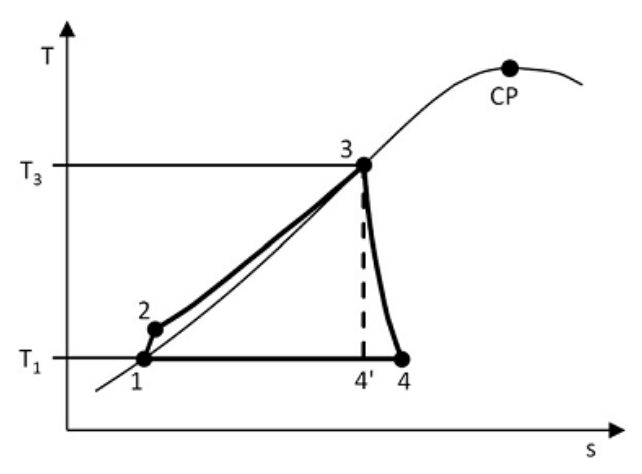

b

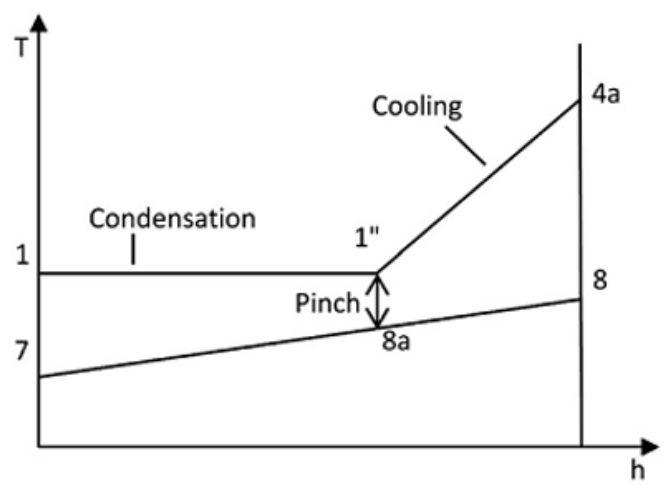

d

Fig. 2. (a) Configuration of TLC system, (b) T-s diagram for TLC system, (c) T,h-diagram for the heat transfer from the working fluid to the cooling agent in the TLC-systems, (d) T,h-diagram for the heat transfer from the working fluid to the cooling agent in the ORC systems

environmental impact of the trigeneration system. Also, increasing the turbine inlet temperature decreases the cost of environmental impact, primarily by reducing the combustion chamber mass flow rate. Table 3 shows the parametric study results from energy and exergy analyses of the system. The exergy analysis results are graphically shown in Fig 3(a). It shows that the highest exergy destruction occurs in the combustion chamber (CC). Both exergy destruction and the dimensionless exergy destruction ratio are higher in the combustor than in other components.Fig 3 (b) shows the variation with compressor pressure ratio of both exergy efficiency and exergy destruction for the system. Result shows that fuel consumption decreases as the compressor pressure ratio increases, due to the increase of the air temperature entering the combustion chamber and the corresponding reduction in fuel consumption. Consequently, the net work output first increases and then decreases as compressor pressure ratio increases. To provide environmental insights, the environmental impact of the gas turbine cycle is compared to that of the trigeneration in Fig 3 (c). It is seen that the trigeneration cycle has less $\mathrm{CO} 2$ emissions than the GT and CHP cycles, providing a significant motivation for the use of trigeneration cycles. It is also observed that trigeneration has a higher exergy efficiency than other cycles. The variation of $\mathrm{CO} 2$ emission and sustainability index with compressor pressure ratio is shown in Fig 3 (d). Fig 3 (e) shows that increasing the compressor pressure decreases the cost of environmental impact, due to the reduction of mass flow rate injected into the combustion chamber. Thus, the sustainability index increases. Fig 3 (f) shows the effect of compressor pressure ratio on total exergy destruction rate of the cycle and sustainability index. It is observed that, the overall exergy destruction of the cycle decreases and the sustainability index increases with increasing compressor pressure ratio. Fig 3 (g) shows the effect of varying gas turbine inlet temperature (GTIT) on the cycle's total exergy destruction rate and sustainability index. The sustainability index is seen to increase with gas turbine inlet temperature.

Xingyang Yang et al. [8] [2016] analysed a novel combined power and ejector-refrigeration cycle using zeotropic mixture. A novel combined power and ejectorrefrigeration cycle using zeotropic mixture is proposed. In the combined cycle, the turbine exhaust from the organic Rankine cycle entrains the vapour from the ejector-refrigeration cycle. And the zeotropic mixture is divided into the power cycle and the ejector refrigeration cycle through a vapour-liquid separator. And these two flows have different composition. The cycle performance with different fluid composition is evaluated and it is compared with a conventional combined cycle. It is found that the cycle exergy achieves a maximum value of $10.29 \%$ with mixture isobutane/pentane $(40 \% / 60 \%)$, and the thermal efficiency gets a maximum value of $10.77 \%$ with mixture isobutane/pentane $(70 \% / 30 \%)$. The temperature glide in the evaporator achieves a maximum value of $15.09 \mathrm{~K}$ with mixture isobutane/pentane $(80 \% / 20 \%)$. 


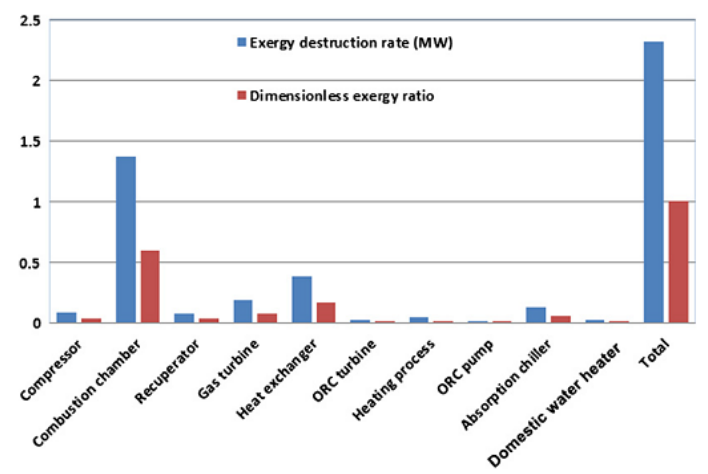

a

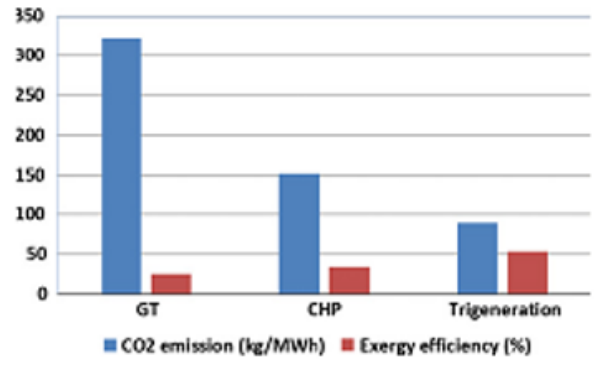

$\mathrm{c}$
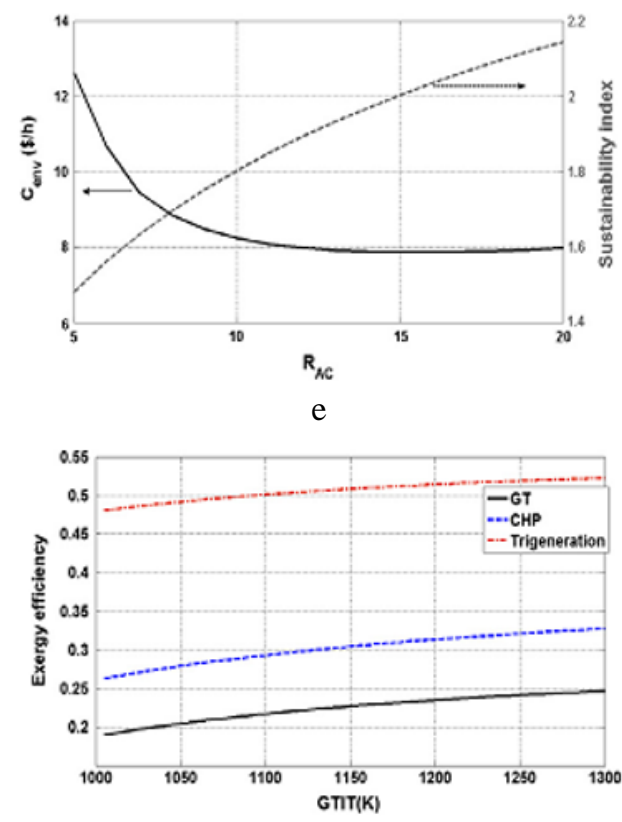

$\mathrm{g}$

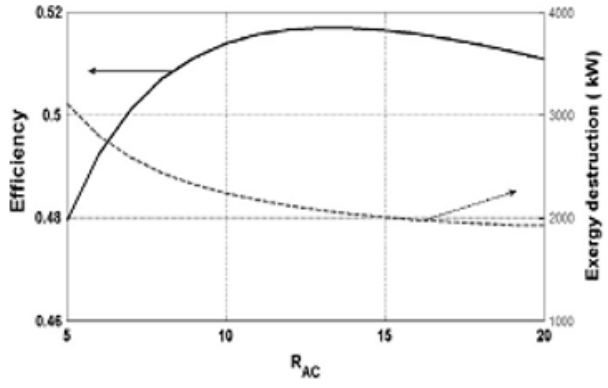

b

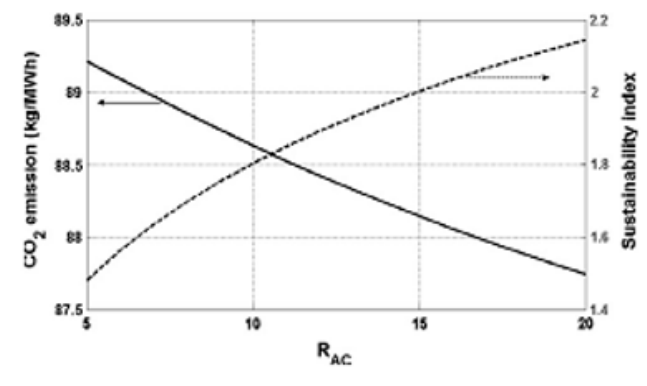

d

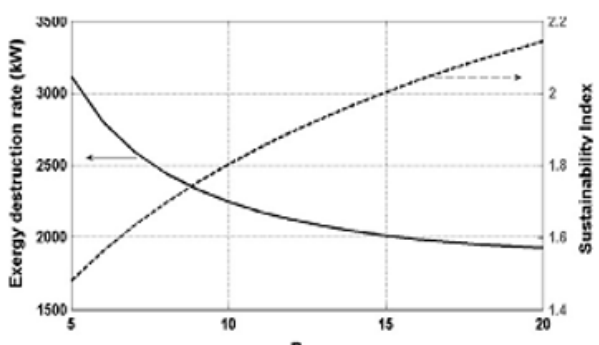

$R_{\text {an }}$

$\mathrm{f}$

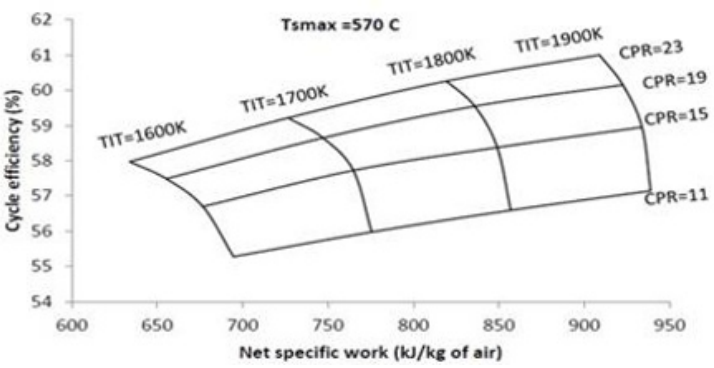

$\mathrm{h}$

Fig. 3. (a) Exergy destruction rate and dimensionless exergy efficiency for the trigeneration system and each of its components, (b) Variation with compressor pressure ratio of exergy efficiency and exergy destruction rate for the trigeneration system, (c) Comparison of exergy efficiency and environmental impact of different types, (d) Variation with compressor pressure ratio of sustainability index and $\mathrm{CO}_{2}$ emission, (e) Variation with compressor pressure ratio of sustainability index and cost rate of environmental impact, (f) Variation with compressor pressure ratio of total exergy destruction rate and sustainability index, (g) Variation of gas turbine inlet temperature of exergy efficiency for several cycles, (h) Effect of TIT and cycle pressure ratio on net specific work output and efficiency of combined cycle

The parametric analysis shows that the cycle performs better in lower condenser temperature though the refrigeration cycle.

G. Praveen Kumar et al. [9] [2017] studied combination of $\mathrm{NH} 3-\mathrm{H} 2 \mathrm{O}$ absorption refrigeration cycle and Kalina extraction turbine cycle that uses low-grade energy. The expected performance characteristics of the dual output system were first evaluated using an energetic and exergetic approach based on the quality of useful outputs; in the experimental confirmation. It was evaluated in Cooling Alone mode (CA mode) and Combined Cooling-Power mode (CCP mode), for the same operating conditions. The weak solution flow rate and generator temperature were maintained constant at 
Table 3. Parametric study results from energy and exergy analyses of the system.

\begin{tabular}{lll} 
Parameter & & Value \\
\hline Fuel mass flow rate & $\dot{m}_{f}(\mathrm{~kg} / \mathrm{s})$ & 0.068 \\
Heating load & $\dot{Q}_{\text {Heating }}(\mathrm{kW})$ & 819.5 \\
Cooling load & $\dot{Q}_{\text {Coooing }}(\mathrm{kW})$ & 199.8 \\
Net output power & $\dot{W}_{\text {net }}(\mathrm{kW})$ & 1500 \\
Energy efficiency & $\eta_{T r i}$ & 0.89 \\
Exergy efficiency & $\psi_{T r i}$ & 0.55 \\
Total exergy destruction rate & $\dot{E x}_{D, T \text { Total }}(\mathrm{kW})$ & 2172 \\
Specific $\mathrm{CO}_{2}$ emission & $\mathrm{CO}_{2}$ emission $(\mathrm{kg} / \mathrm{MWh})$ & 88.2 \\
Cost rate of environmental impacts & $\dot{C}_{\text {env }}(\$ / \mathrm{h})$ & 7.54 \\
Hot water mass flow rate & $\dot{m}_{\text {hoow }}$ & 3.27 \\
Absorption chiller COP & $\mathrm{COP}$ & 0.44 \\
\hline
\end{tabular}

$0.237 \mathrm{~kg} / \mathrm{s}$ and $133^{\circ} \mathrm{C}$ respectively throughout the experimental run. The maximum cooling load of 34.26 $\mathrm{kW}$ was achieved with a COP's of 0.57 in CA mode. In CCP mode, the system was operated at a split ratio of 0.5 with the useful cooling load of $15.26 \mathrm{~kW}$ and estimated expander load of $2.21 \mathrm{~kW}$ respectively, with power to cooling ratio of 0.14 . The corresponding effective firstlaw and exergetic efficiencies were $13 \%$ and $48 \%$. This study provides a feasible and flexible way to meet the desired combination of power/ cooling ratio to generate varying demand profiles using available low-grade heat sources.

Zhiwei Ma et al. [10] [2017] studied one doubleeffect, one half-effect and one ejector-combined absorption power generation (APG) cycles based on one of the most widely studied APG cycles - Kalina KCS11. The performance of these advanced cycles were numerically analyzed and compared against KCS-11 in terms of power output, energy and exergy efficiencies. An optimal mass fraction of ammonia- water solution used in KCS-11 has been identified to achieve the maximum energy and exergy efficiencies, which were $0.09-0.14$ and $0.65-0.72$ respectively when using $70.0-$ $100.0^{\circ} \mathrm{C}$ boiling temperature; however, the corresponding power output was only $23.0-48.0 \%$ of its maximum potential. The double-effect APG cycle could effectively improve the energy and exergy efficiencies by $3.6-12.6 \%, \quad 10.7-28.2 \%$ and $19.0-900.0 \%$ respectively when using $100^{\circ} \mathrm{C}, 120^{\circ} \mathrm{C}$ and $140^{\circ} \mathrm{C}$ boiling temperature; but its power output capacity was about $43.0-63.0 \%$ lower. The half-effect cycle could provide larger pressure ratio for power generation, which amplified the power output by 50.0-85.0 \% but sacrificed its energy and exergy efficiencies by 4.0 $45.0 \%$ compared to that of KCS- 11 . To pursue higher energy and exergy efficiencies without a bulky two-stage system, one can replace the throttling valve and mixer in KCS-11 by an ejector to form a ejector-combined APG cycle, which could improve the system energy efficiency by $2.9-6.8 \%$ when using $80^{\circ}-100^{\circ} \mathrm{C}$ boiling temperature, while the power output capacity was only slightly influenced.
Jie Jia et al. [11] [2017] simulated and analysed an ORC system driven by the waste heat recovered from a trigeneration system. The ORC system can be used to transfer the waste heat from a diesel engine in a triggeneration system to electricity. When the electrical energy demand is high and there is no heat/cooling demand, waste heat can be transferred from ORC system to electrical power. The result shows increase in the transfer efficiency of recovered waste heat to electricity at the steady state operation condition. The amount of electricity output increase linear when the mass flow rate increases. Combined with the ORC and the heat recovery system, the tri-generation system supplies different energy product with a high efficiency. The ORC and the heat recovery system could recover the waste heat with a high efficiency, which utilizes the waste energy stored in the exhaust gas and the coolant.

Simin Anvari et al. [12] [2017] analysed thermoeconomical consideration of regenerative organic Rankine cycle coupled with the absorption chiller systems. The obtained results indicated that the utilization of the waste heat of GT-HRSG cycle in the RORC cycle lead to a negligible increase in the cycle's cost, it allows for a considerable increase of the exergetic efficiency of the GT-HRSG/RORC cycle. Additionally, application of waste heat of GT-HRSG/RORC cycle in the cooling absorption cycle, the exergy efficiency of the cycle increases while it raises the overall CCHP cycle costs marginally.

K.F. Fong et al. [13] [2017] thermodynamically investigated climatic effect on the energy performance of trigeneration. A set of energy performance indicators were applied to thoroughly appraise the trigeneration systems against the conventional provisions. It was found that the extent of energy merit of trigeneration depended on the utilization degree of waste heat, which was associated to the electrical efficiency of prime mover and the building loads caused by climatic effect. Energy saving potential of trigeneration might not be guaranteed in certain occasions in a year.

Kumar \& Singh [14] [2012] thermodynamically analysed gas/steam combined cycle with respect to variation in Turbine Inlet Temperature (TIT) in both 
topping and bottoming cycles, for air transpiration cooled gas turbine. The performance of combined cycle with dual pressure HRSG has been examined for different cycle pressure ratios varying from 11 to 23 and TIT varying from $1600 \mathrm{~K}$ to $1900 \mathrm{~K}$. Researchers found that both the cycle efficiency and specific work increased with TIT for each pressure ratio. There exists an optimum pressure ratio for cycle efficiency and specific work for each TIT. The best cycle performance was seen at a TIT of $1900 \mathrm{~K}$ for maximum steam temperature of $570^{\circ} \mathrm{C}$, at the cycle pressure ratio of 23 , which gave the cycle efficiency of 60.9 percent with net specific work of $909 \mathrm{~kJ} / \mathrm{kg}$. Fig 3(h) graphically shows the effect of TIT and cycle pressure ratio on net specific work output and efficiency of combined cycle.

Sanjay et al. [15] [2008] performed comparative study of the influence of different means of turbine blade cooling on the thermodynamic performance of combined cycle power plant. Study has been done which comprised seven schemes involving air and steam as coolants under open and closed loop cooling techniques. The open loop incorporates the internal convection, film and transpiration cooling techniques while Closed loop cooling includes only internal convection cooling. Study shows that closed loop steam cooling provides more specific work and consequently gives higher value of plant efficiency of about $60 \%$, whereas open loop transpiration steam cooling, open loop steam internal convection cooling, transpiration air cooling, film steam cooling, film air, and internal convection air cooling reports lower values of plant efficiency in decreasing order as compared to closed loop steam cooling.

Shukla \& Singh et al. [16] [2017] studied three systems in combination namely inlet fogging, steam injection in combustor, and film cooling of gas turbine blade for performance enhancement of gas/steam combined cycle power plant. Aim of the study is to enhance the gas turbine thermal efficiency and specific power output. To achieve this the research and development work has centered on improving firing temperature, cycle pressure ratio, adopting improved component design, cooling and combustion technologies, and advanced materials and employing integrated system (e.g. combined cycles, intercooling, recuperation, reheat, chemical recuperation). Researcher evaluated the integrated effect of inlet fogging, steam injection and film cooling on the gas turbine cycle performance in this research work. First law of thermodynamics was used for thermodynamic modelling of gas/steam combined cycle system in this study. The results shows that inlet fogging for inlet air cooling could increase the thermal efficiency of gas/steam combined cycle and inlet fogging air cooling, steam injection and film cooling on topping cycle improves the performance of gas/steam combined cycle power plant.Alongwith this, study reveals that the steam injection in the combustion chamber increases the mass of expanding fluid in the gas turbine, which enhances the performance parameters of the gas/steam combined cycle. Researcher found that the gas/steam combined cycle configuration with inlet fogging cooling, steam injection \& film cooling is good combination for obtaining better efficiency and power.

Sanjay et al. [17] [2008] studied with the development requirements of a gas-steam combined cycle power plant with the aim to achieve plant efficiency in excess of 62 per cent through various possibilities of performance enhancement in topping cycle and bottoming cycle. Researcher considered the reference-combined cycle configuration (MS9001 series) power plant of General Electric. The possible area of improvements are searched which include the increase in rotor/turbine inlet temperature; development of advanced high-temperature blade material with superior thermal barrier coatings; advanced inlet duct and compressor inlet design to minimize loss; improved individual component efficiencies; improved turbine blade cooling techniques; better blade cooling mediums; incorporating intercooling and reheat either separately or in combination with the simple gas turbine cycle using higher cycle pressure ratio; improved gas turbine exhaust heat utilization in the heat recovery steam generator, minimize stack gas temperature; as well as best shaft system configuration. Researcher quantifies each of these development possibilities and shows that on incorporating these factors in the reference cycle it could offer the combined cycle plant efficiency above 65 per cent.

Kumar \& Singh et al. [18] [2011] evaluated the performance of a transpiration-cooled gas turbine for different coolants and permissible blade temperatures considering the effect of radiation. The thermodynamic study shows that the theoretical coolant requirement increases so as to be close to the actual requirement and hence the cycle performance is affected accordingly with consideration of the radiation effect.

\subsection{Energy, Exergy, Economical and Environmental Study Based Systems}

Bassols et al. [19] [2002] studied energy, exergy analysis of trigeneration plants in the food industry. Minciuc et al. [20- 21] [2003] analysed trigeneration systems from the point of view of fuel saving and environmental impact. Temir and Bilge [22] [2004] studied and analysed trigeneration plants from the thermos-economic point of view which produces electrical power with a natural gas fed reciprocating engine. Ribarov and Liscinsky [23] [2007] discussed the CCHP system for achieving economic viability through significant improvements in fuel utilisation. Khaliq and Kumar [24] [2008] analysed energy and exergy of gas turbine based trigeneration system and reported the effect of pressure ratio and process heat pressure on the performance parameters. Khaliq [25] [2009] further reported the impact of operating parameters on energetic and energetic efficiency of trigeneration system for optimisation purposes.

Mohammad Ameri et al. [26] [2010] studied energy and exergy analysis of a tri-generation system based on micro-gas turbine with a steam ejector refrigeration system. Fig 4 (a) and Fig 4 (b) graphically represents the 


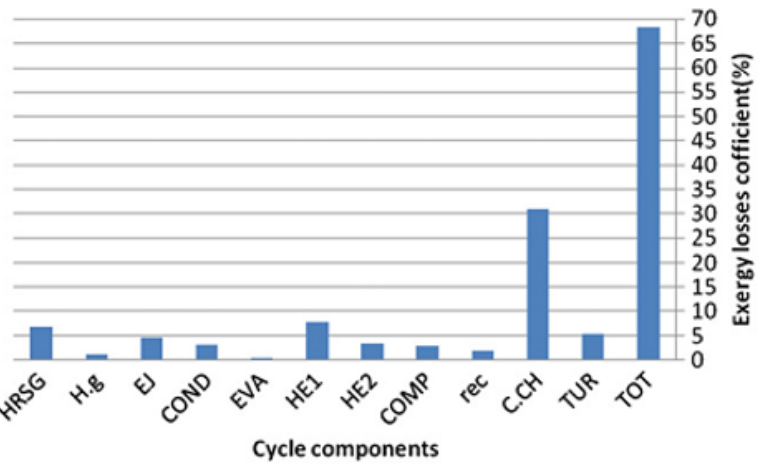

a

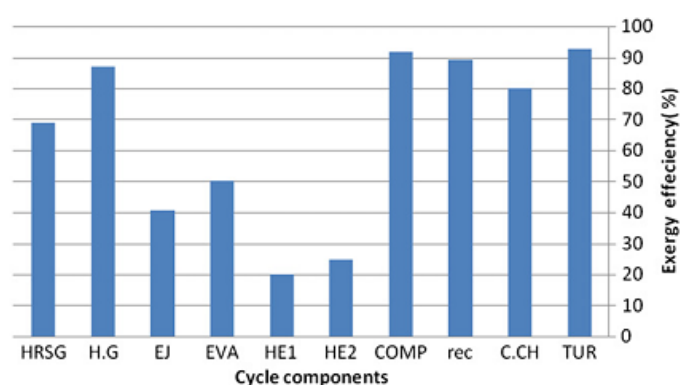

b

Fig. 4. (a) Exergy losses coefficient for system components, (b) Exergy efficiency of system components

results related to exergy losses and exergy efficiency of the system components respectively. Yaping Chen et al. [27] [2015] analyzed an integrated system of AWKRC (Ammonia Water Kalina Rankine cycle) for power and heating. Giovanni Angrisani et al. [28] [2016] studied performance indices such as energy based indices, environmental indices and economic indices and methodologies to assess the performances of cogeneration and trigeneration systems. According to the environmental analysis combined production is more convenient for countries in which the electric separate production is mainly based on fossil fuel, and combined production of cooling and electric energy is not convenient, because of the recovered amount of thermal energy available from the CHPs is not totally used. Keyvan Bahlouli et al. [29] [2016] reported that the energy content of exhaust gases of the HCCI engine are used to drive the bottoming cycles including a steam turbine cycle and an absorption heat transfer cycle in a cogeneration system.

Mahesh. N. Shelar et al. [30] [2016] compared energy and exergy analysis of diesel engine powered two trigeneration systems integrated with absorption chillers. With trigeneration system integrated with only single effect chiller, the exergy destruction per ton is more than twice the corresponding value from system with two chillers. This can be attributed to lower chilling effect as well as increase in irreversibility in a system using a single chiller. This irreversibility is captured by exergy destruction in exhaust heat exchanger that occurs in system with single chiller. Better temperature matching of waste energy source with the application meaning using two chillers would lower this irreversibility. The performance of trigeneration system with two chillers is better than that of a system with a single chiller based on energetic, exergetic as well as economic perspective for the trigeneration system under consideration. K.F. Fong [31] [2017] investigated trigeneration system using two sets of diesel-engine prime movers for a highrise reference office building in a subtropical city. Through the year-round dynamic simulation, the dispatch of absorption chiller and compression chiller in trigeneration system has been identified. In the paradigm of trigeneration, it is natural to emphasize on the use of waste heat to drive the equipment, like the absorption chiller In the regions with hot and humid climate, the cooling demand is generally not enough if solely offered by the equipment. It is inevitable to involve the electrical compression chiller. Particularly in the summer time, the involvement of compression chiller would be so frequent that it is close to $90 \%$ of the operating time. As a result, the primary or secondary role of certain chiller type would be switched over in different seasons in trigeneration. Proper dispatch of the thermally activated absorption chiller and the electrically driven compression chiller is essential to maintain a selfsufficient cooling supply for building, as well as to minimize the energy need from power grid at the same time. The role of compression chiller is no more auxiliary, but active in operation in the hot and humid climate from a year-round perspective.

Y. Sanjay et al. [32] [2007] performed energy and exergy analysis of reheat gas-steam combined cycle with the help of closed-loop-steam-cooling. Closed-loopsteam-cooling has been found to be superior to air-film cooling of the blade cooling techniques. Researcher analysed that the reheat gas-steam combined cycle plant reports enhanced thermal efficiency (around 62\%) and plant specific work as compared to basic steam-gas combined cycle with air-film cooling as well as closedloop-steam cooling. Further, the plant efficiency, reaches an optimum value in higher range of compressor pressure ratio as compared to that in film air-cooling with closed-loop-steam-cooling. Along with this, study shows that reheat pressure is an important design parameter and its optimum value gives maximum plant efficiency. Study based on the second-law-model (exergy analysis) shows that the maximum inefficiencies is related to combustion-chamber $(30 \%)$, followed by that in gas turbine $(4 \%)$ of steam cooled-reheat gassteam combined cycle. Many researchers analysed thermodynamically, exergo-economically and environmentally of trigeneration systems [33-38] [2014, 2017, 2018].

\subsection{Energy Sources Based Systems}

W.R. Wagar et al. [39] [2010] studied an ammoniawater Rankine cycle where renewable energy (solar, geothermal, biomass, oceanic-thermal, and nuclear as 
Table 4. Comparison between solar absorption and adsorption systems.

\begin{tabular}{|c|c|c|}
\hline Specification & Closed sorption cycle & \\
\hline System & Absorption & Adsorption \\
\hline Sorbent type & Liquid & Solid \\
\hline Working pair & $\mathrm{H}_{2} \mathrm{O} / \mathrm{LiBr}, \mathrm{NH}_{3} / \mathrm{H}_{2} \mathrm{O}$ & $\mathrm{H}_{2} \mathrm{O} /$ silica-gel \\
\hline Operating temperature & $60-110^{\circ} \mathrm{C}$ (single-stage) & $53-82^{\circ} \mathrm{C}$ \\
\hline $\operatorname{COP}[-]$ & $\begin{array}{l}0.50-0.73 \text { (single-stage) } \\
<1.3 \text { (two-stage) }\end{array}$ & 0.59 \\
\hline EER $[\mathrm{Btu} /(\mathrm{Wh})]$ & $\begin{array}{l}1.71-2.49 \text { (single-stage) } \\
<4.44 \text { (two-stage) }\end{array}$ & 2.01 \\
\hline Advantages & $\begin{array}{l}\text { Only one moving part (pump) with possibly no } \\
\text { moving part for a small system } \\
\text { Low temperature heat supply is possible }\end{array}$ & $\begin{array}{l}\text { No moving part (except valve) } \\
\text { Low operating temperature can be achieved } \\
\text { Thermal COP is quite high compared to other heat operating systems }\end{array}$ \\
\hline Disadvantages & $\begin{array}{l}\text { Low COP } \\
\text { It cannot achieve a very low evaporating } \\
\text { temperature } \\
\text { The system is quite complicated }\end{array}$ & $\begin{array}{l}\text { Low operating pressure requirement makes it difficult to achieve air-tightness } \\
\text { Very sensitive to low temperature especially the decreasing temperature during } \\
\text { night-time } \\
\text { It is an intermittent system }\end{array}$ \\
\hline
\end{tabular}

Table 5. Technical parameters for the reference scenario (Turbec T100) and results of the selected case studies. Air temperature at compressor outlet: $214{ }^{\circ} \mathrm{C}$; TIT: $950{ }^{\circ} \mathrm{C}\left(900{ }^{\circ} \mathrm{C}\right.$ for $100 \%$ biomass $)$; air mass flow-rate in micro gas-turbines $0.783 \mathrm{~kg} / \mathrm{s}$.

\begin{tabular}{llcccc}
\hline Case study & Unit & Ref. [22] & A & B & C \\
\hline Biomass energy ratio (biomass/total input) & $\%$ & 0 & 0 & 50 & 100 \\
Net electric power output (ISO conditions) & $\mathrm{kW}$ & 100 & 100 & 90 & 78 \\
Total thermal power input $\dot{E}_{\text {Lit.5s }}$ & $\mathrm{kW}$ & 333 & 333 & 373 & 404 \\
Biomass thermal power input & $\mathrm{kW}$ & - & - & 187 & 404 \\
NG thermal power input & $\mathrm{kW}$ & 333 & 333 & 187 & 0 \\
GT shaft power & $\mathrm{kW}$ & 115 & 111 & 104 & 95 \\
Turbine power & $\mathrm{kW}$ & 279 & 279 & 272 & 263 \\
Net electric-efficiency ISO & $\%$ & 29.9 & 30.1 & 24.0 & 19.2 \\
Gas temperature at turbine exit & ${ }^{\circ} \mathrm{C}$ & 654 & 653 & 656 & 609 \\
Gas temperature after recuperator & ${ }^{\circ} \mathrm{C}$ & 270 & 270 & 272 & 262 \\
MGT air mass flow rate & $\mathrm{kg} / \mathrm{s}$ & 0.783 & 0.783 & 0.783 & 0.783 \\
Furnace air mass flow rate & $\mathrm{kg} / \mathrm{s}$ & - & - & 0.300 & 0.600 \\
Furnace maximum air temperature & ${ }^{\circ} \mathrm{C}$ & - & - & 763 & 900 \\
Furnace fan power & $\mathrm{kW}$ & - & - & 4.24 & 8.25 \\
HTHE surface area & $\mathrm{m}^{2}$ & - & - & 34.3 & 132.1 \\
MGT recuperator surface area & $\mathrm{m}^{2}$ & 164 & 135 & 135 & 135 \\
Air preheater surface area & $\mathrm{m}^{2}$ & - & - & 60 & 110 \\
\hline
\end{tabular}

well as industrial waste heat) was used as energy source. Due to the nature of the ammonia-water mixture, changes in its concentration allow thermodynamic cycles to adapt to fluctuations in renewable energy sources, which is an important advantage with respect to other working fluids. The non-linearity of the working fluid's behaviour imposes that each cycle must be optimized based upon several parameters. A model has been developed to optimize the thermodynamic cycle for maximum power output and carry out a parametric study. The lowest temperature state of the system is fixed, and three other parameters are variables of study, namely, maximum system temperature, ammonia concentration and energy ratio, which is a newly introduced parameter. Energy ratio indicates the relative position of the expansion state and is defined in terms of enthalpies. The study is conducted over a concentration range of $0-0.5$; the maximum temperature studied varies between $75^{\circ} \mathrm{C}$ and $350^{\circ} \mathrm{C}$ for extreme cases, and the energy ratio from saturated liquid to superheated vapour. As a result, the optimal expansion energy ratio is predicted. The cycle efficiencies are drastically affected by the concentrations and temperatures. Depending on the source temperature, the cycle energy efficiency varies between $5 \%$ and $35 \%$ representing up to $65 \%$ of the Carnot limit. The optimal energy ratio has been determined for several concentrations. Hanna Mergner et al. [40] [2015] studied ammonia water based cycles for power generation from low enthalpy heat sources.

\subsubsection{Fuel Cell Based Systems}

Faramarz Ranjbar et al. [41] [2014] analyzed a novel trigeneration system based on a solid oxide fuel cell (SOFC). Paul E. Dodds et al. [42] [2015] studied hydrogen and fuel cell technologies for heating. M. Mortazaei et al. [43] [2016] performed thermodynamic and environmental analysis of CCHP system via biomass based SOFC. Leyla Khani et al. [44] [2016] evaluated a CHP system from exergoeconomic point of view based on a SOFC.

\subsubsection{Solar Based Systems}

Ioan Sarbu et al. [45] [2015] reviewed solar closed sorption (absorption and adsorption) refrigeration 
Table 6. Presents the input parameters and the results of the energy, economic and environmental analysis.

\begin{tabular}{lr}
\hline Electricity power $(\mathrm{kWe})$ & 25 \\
Heat source thermal power $(\mathrm{kWt})$ & 250 \\
Heat sink (heating) thermal power $(\mathrm{kWt})$ & 180 \\
Heat sink (absorption) thermal power $(\mathrm{kWt})$ & 26 \\
Absorption COP $(-)$ & 0.75 \\
Absorption cooling capacity $(\mathrm{kWt})$ & 19.5 \\
Operating time (with heating usage) $(\mathrm{h})$ & 4000 \\
Operating time (without heating usage) $(\mathrm{h})$ & 4000 \\
Electricity generation $(\mathrm{kWh})$ & 200000 \\
Biomass consumption $(\mathrm{kWh})$ & 2000000 \\
Cooling energy $(\mathrm{kWh})$ & 156000 \\
Heating energy $(\mathrm{kWh})$ & 720000 \\
Electricity price $(€ / \mathrm{kWh})$ & 0.115 \\
Cooling price $(€ / \mathrm{kWh})$ & 0.055 \\
Heating price $(€ / \mathrm{kWh})$ & 0.065 \\
Biomass cost $(€ / \mathrm{kWh})$ & 0.025 \\
Net cash flow $(€)$ & 28380 \\
Biomass consumption emission rate $\left(\mathrm{kgCO}_{2} / \mathrm{kWh}\right)$ & 0.018 \\
Electricity production emission rate $(\mathrm{kgCO} / \mathrm{kWh})$ & 0.339 \\
Cooling energy $\mathrm{emission}$ rate $(\mathrm{kgCO} / \mathrm{kWh})$ & 0.192 \\
Heating energy emission rate $(\mathrm{kgCO} / \mathrm{kWh})$ & 0.311 \\
Emission reduction $(\mathrm{kgCO}$ & 285610 \\
\hline & \\
\hline
\end{tabular}

systems and analysed environmental aspect of the systems. solar-powered adsorption refrigeration devices can meet, among things, the needs for refrigeration, airconditioning applications and ice making, with great potential for the conservation of various goods (medicines, food supplies) in remote areas. Nevertheless, the purpose of each system and the ambient conditions dictate its configuration (type of solar collector) and working pair, and therefore its performance. Table 4 shows the comparison between solar absorption and adsorption systems.

Deb et al. [46] [2016] proposed solar thermal system which facilitates the process heat for industrial purposes. The recovered heat at the concentrator plate transferred to the air flow at the rear space of the system \& the water flowing through the embedded pipes remains at a lower temperature with an arrangement of concentrator reflectivity of around $75 \%$ which implies $25 \%$ of the incident solar irradiation heat is recovered for system enhancement to reduce volume \& weight for same heat output without heat recovery with a consequence of reduced cost . The use of low cost concentrator material with supporting structure in comparison to the glass facets is another advantage of the system. Many researchers reported thermodynamic, exergoeconomic and environmental studies of different trigeneration systems with solar as primary energy source [47-50] [2016, 2017].

\subsubsection{Biomass Based Systems}

Antonio M Pantaleo et al. [51] [2017] analyzed energy performance and thermo-economic assessment of a micro turbine based dual-fuel gas-biomass trigeneration system. The assumed technical parameters for the simulations and the results of the Gate-Cycle modelling effort using different biomass-to-natural gas (NG) input ratios are reported. in Table 5, The results show that the 
overall net electric efficiency decreases when increasing the biomass input. This depends on combination of following factors: (i) an increase in the exhaust heat losses; (ii) the lower biomass combustion efficiency; (iii) the increase of the parasitic electricity consumption of the air fan; and (iv) the increased pressure losses that reduce the pressure expansion ratio across the turbine. The research shows a thermo-economic simulation with different fuel types and energy demand typology, investigating the influence of key factors on investment profitability and global conversion efficiency, on the basis of the Italian legislative scenario and supporting policy measures.

Joaquin Navarro-Esbrí et al. [52] [2017] analyzed CCHP system, based on an ORC, using biomass as a renewable heat source for energy saving and emissions reduction in a supermarket. Table 6 presents the input parameters and the results of the energy, economic and environmental analysis. The parameters used in this multitarget analysis (for instance annual operating time, energy costs and emission rates among others) are based on the operating conditions measured for an existing supermarket. Thermodynamic analysis, exergy analysis and multiobjective optimization of biomass gasification based multigeneration system has been studied by different researchers [53-54] [2014, 2016].

\section{Conclusion}

Most conventional power generation systems are based on fossil fuels, which result in a huge amount of greenhouse gases (GHG) emissions. Hence, it is need of the day to explore the renewable sources or to use the low-grade waste heat from the power generation process for heating and/or cooling. It will be one of the solutions to save the energy squandering, and thus trigeneration technologies are quite relevant in present perspective. Present study shows thatthe degree of improvement of a trigeneration system is sensitive to the performance and operating parameters of each unit and the approach used to integrate these units into the single system. Therefore, energy, exergy, and environmental study of any proposed system are important to assess the system performance and to examine the possible degree of improvement in the system. The exergy analysis helps in identifying and quantifying the sources of the irreversibilities in the system that are associated with each component. The environmental analysis shows how much reduction in $\mathrm{CO}_{2}$ emissions when the trigeneration system is used, as compared to a simple electrical power system. Economical study reports how generation of power locally and its consumption from the distribution companies and using it for the cooling and heating most of the times proves to be costlier.

\section{References}

1. Energy Information Administration. International Energy Outlook 2009. U.S.A., 2009.
2. D.W. Wu, R.Z. Wang: 'Combined cooling, heating and power: A review', Progress in Energy and CombustionScience, 2006, 32,459-495.

3. https://www.statista.com/statistics/271748/the largest-emitters-of-co2-in-the-world/.

4. International Energy Agency. Combined heat and power: evaluating the benefits of greater global investment. France, 2008.

5. Calin Zamfirescu, Ibrahim Dincer: 'Thermodynamic analysis of a novel ammonia-water trilateral Rankine cycle', Thermochimica Acta, 2008, 477, 7-15.

6. Johann Fischer: 'Comparison of trilateral cycles and organic Rankine cycles', Energy, 2011, 36, 6208-6219.

7. Pouria Ahmadi, Ibrahim Dincer, Marc A. Rosen: 'Exergo-environmental analysis of an integrated organic Rankine cycle for trigeneration', Energy Conversion and Management, 2012, 64, 447-453.

8. Xingyang Yang, Nan Zheng, Li Zhao, Shuai Deng, Hailong Li , Zhixin Yu : 'Analysis of a novel combined power and ejector-refrigeration cycle', Energy Conversion and Management, 2016, 108,266-274.

9. G. Praveen Kumar, R. Saravanan, Alberto Coronas: 'Experimental studies on combined cooling and power system driven by low-grade heat sources', Energy, 2017, 128, 801-812.

10. Zhiwei Ma, HuashanBao, Anthony Paul Roskilly: 'Principle investigation on advanced absorption power generation cycles', Energy Conversion and Management, 2017, 150, 800-813.

11. Jie Jia ,Cui He ,ZhengXiao ,Chunqiong Miao ,Liqi Luo ,Haisheng Chen, Xinjing Zhang, Huan Guo ,Yaodong Wang, Tony Roskilly:'Simulation study of an ORC system driven by the waste heat recovered from a trigeneration system', Energy Procedia, 2017, 105, 5040 $-5047$.

12. Simin Anvari, HadiTaghavifar, AlirezaParvishi: 'Thermo- economical consideration of Regenerative organic Rankine cycle coupling with the absorption chiller systems incorporated in the trigeneration system', Energy Conversion and Management, 2017, 148, 317329.

13. K.F. Fong, C.K. Lee: 'Investigation of climatic effect on energy performance of trigeneration in building application', Applied Thermal Engineering, 2017, 127, 409-420.

14. Sanjay Kumar, Onkar Singh: 'Effect of Gas/Steam Turbine Inlet Temperatures on Combined Cycle Having Air Transpiration Cooled Gas Turbine ', Int. J. of Thermal \& Environmental Engineering, 2012, 4, 00-00.

15. Sanjay, Onkar Singh, B.N. Prasad: 'Influence of different means of turbine blade cooling on the thermodynamic performance of combined cycle', Applied Thermal Engineering, 2008, 28, 2315- 2326.

16. Anoop Kumar Shukla, Onkar Singh: 'Impact of inlet fogging on the performance of steam injected cooled gas turbine based combined cycle power plant', Gas Turbine India Conference, 2017. 
17. Sanjay, O Singh, and B N Prasad: 'Thermodynamic modeling and simulation of advanced combined cycle for performance enhancement', Part A: Journal of Power and Energy, 2008, 222, 541-556.

18. Sanjay Kumar, Onkar Singh: 'Performance evaluation of a transpiration-cooled gas turbine for different coolants and permissible blade temperatures considering the effect of radiation', Part A: Journal of Power and Energy, 2008, 225, 1156-1165.

19. J. Bassols, B. Kuckelkorn, J. Longneck and R. Schneider: 'Trigeneration in the food industry', Applied Thermal Engineering, 2002, 22, 595-603.

20. E. Minciuc, O. L. Corre, V. Athanasovici, M. Tazerout and I. Bitir: 'Thermodynamic analysis of trigeneration with absorption chilling machine', Applied Thermal Engineering, 2003, 23, 1391-1405.

21. E. Minciuc, O. L. Corre, V. Athanasovici and M. Tazerout: 'Fuel saving and $\mathrm{CO} 2$ emissions for trigeneration system', Applied Thermal Engineering, 2003, 23, 1333-1346.

22. G. Temir and D. Bilge: 'Thermoeconomic analysis of trigeneration system', Applied Thermal Engineering ,2004, 24, 2689-2699.

23. L. A. Ribarov and D. S. Liscinsky: 'Microgrid viability for small scale cooling heating, and power', J. Energ. Resour. ASME, 2007, 129, 1071-78.

24. A. Khaliq and R. Kumar: 'Thermodynamic performance assessment of gas turbine tri generation system for combined heat cold and power production', J. Eng. Gas Turb. Power, 2008, 130, 1-4.

25. A. Khaliq: 'Energy analysis of gas turbine trigeneration system for combined production of power heat and refrigeration', Int. J. Refrig., 2009, 32, 534545.

26. Mohammad Ameri, Ali Behbahaninia, Amir Abbas Tanha: 'Thermodynamic analysis of a tri-generation system based on micro-gas turbine with a steam ejector refrigeration system', Energy, 2010, 35, 2203-2209.

27. Yaping Chen, Zhanwei Guo, Jiafeng Wu ,Zhi Zhang, Junye Hua: 'Energy and exergy analysis of integrated system of ammonia water Kalina Rankine cycle', Energy, 2015, 90(2), 2028-2037.

28. Giovanni Angrisani, Atsushi Akisawa, Elisa Marrasso , Carlo Roselli, Maurizio Sasso: 'Performance assessment of cogeneration and trigeneration systems for small scale applications', Energy Conversion and Management, 2016, 125, 194-208.

29. Keyvan Bahlouli, Rahim Khoshbakhti Saray: 'Energetic and exergetic analyses of a new energy system for heating and power production purposes', Energy, 2016, 106, 390-399.

30. Mahesh. N. Shelar, S.D.Bagade, G.N. Kulkarni: 'Energy and Exergy analysis of diesel engine powered 27-37.

trigeneration systems', Energy Procedia, 2016, 90,

31. K.F. Fong: 'Investigation on year-round dispatch of multiple chillers in trigeneration system for high-rise building application', Energy Procedia, 2017, 142, 1502 1508 .

32. Y. Sanjay, Onkar Singh, B.N. Prasad: 'Energy and exergy analysis of steam cooled reheat gas-steam combined cycle', Applied Thermal Engineering, 2007, 27, 2779-2790.

33. Ioan Sarbu, Calin Sebarchievici: 'Energy and exergy assessments of a novel trigeneration system based on a solid oxide fuel cell', Energy Conversion and Management, 2014, 87, 318-327.

34. Roberto Leiva-Illanes, Rodrigo Escobar, José M. Cardemil, Diego-César Alarcón-Padilla: 'Thermoeconomic assessment of a solar polygeneration plant for electricity, water, cooling and heating in high direct normal irradiation conditions', Energy Conversion and Management, 2017, 151, 538-552.

35. Xiaofeng Zhang, Hongqiang Li, Lifang Liu, Chengying Bai, Shuang Wang, Quanbin Song, Jing Zeng, Xiaobo Liu, Guoqiang Zhang: 'Exergetic and exergoeconomic assessment of a novel CHP system integrating biomass partial gasification with ground source heat pump', Energy Conversion and Management. 2018,156, 666-679.

36. Pooria Behnam,Alireza Arefi,Mohammad Behshad Shafii:"Exergetic and thermoeconomic analysis of a trigeneration system producing electricity, hot water, and fresh water driven by low-temperature geothermal sources', Energy Conversion and Management,2018,157, 266-276,

37. Hialeah Rashidi, Jamshid Khorshidi: 'Exergoeconomic analysis and optimization of a solar based multigeneration system using multiobjective differential evolution algorithm', Journal of Cleaner Production., 2018, 170, 978-990.

38. Suthida Authayanun, Viktor Hacker:'Energy and exergy analyses of a stand-alone HT-PEMFC based trigeneration system for residential applications', Energy Conversion and Management, 2018, 160, 230-242.

39. W.R. Wagar, C. Zamfirescu, I. Dincer: 'Thermodynamic performance assessment of an ammonia-water Rankine cycle for power and heat production', Energy Conversion and Management, 2010, 51, 2501-2509.

40. Hanna Mergner, Thomas Weimer: 'Performance of ammonia water based cycles for power generation from low enthalpy heat sources', Energy, 2015, 88, 93-100.

41. Faramarz Ranjbar, Ata Chitsaz, S.M.S. Mahmoudi, Shahram Khalilarya, Marc A. Rosen: 'Energy and exergy assessments of a novel trigeneration system based on a solid oxide fuel cell', Energy Conversion and Management, 2014, 87,318-327.

42. Paul E. Dodds, Iain Staffell, Adam D. Hawkes, Francis Li , Philipp Grunewald, Will McDowall, Paul Ekins: 'Hydrogen and fuel cell technologies for heating: A review', International journal of hydrogen energy,2015, 40, 2065 -2083.

43. M. Mortazaei, M. Rahimi: 'A comparison between two methods of generating power, heat and refrigeration 
via biomass based Solid Oxide Fuel Cell: A thermodynamic and environmental analysis', Energy Conversion and Management, 2016, 126, 132-141.

44. Leyla Khani, S. Mohammad S. Mahmoudi, Ata Chitsaz, Marc A. Rosen: 'Energy and exergoeconomic evaluation of a new power/cooling cogeneration system based on a solid oxide fuel cell', Energy, 2016, 94, 6477.

45. Ioan Sarbu, Calin Sebarchievici: 'General review of solar-powered closed sorption refrigeration systems', Energy Conversion and Management, 2015, 105, 403422.

46. S.K Deb, B.C.Sharma:'Trigeneration Solar Thermal System', Procedia Computer Science, 2017, 111,427434.

47. A. Baghernejad, M. Yaghoubi, K. Jafarpur: 'Exergoeconomic optimization and environmental analysis of a novel solar-trigeneration system for heating, cooling and power production purpose', SolarEnergy,2016, 134,165-179.

48. Luca Cioccolanti, Mauro Villarini, Roberto Tascioni, Enrico Bocci: 'Performance assessment of a solar trigeneration system for residential applications by means of a modelling study', Energy Procedia, 2017, 126,445-452.

49. R. Borgogno, S. Mauran, D. Stitou, G. Marck: 'Thermal-hydraulic process for cooling, heating and power production with low-grade heat sources in residential sector', Energy Conversion and Management, 2017, 135,148-159.

50. Dheeraj Kishor Johar,Dilip Sharma,Shyam Lal Soni,Rahul Goyal,Pradeep K. Gupta:'Experimental investigation of thermal storage integrated micro trigeneration system',Energy Conversion and Management, 2017,146,87-95.

51. Antonio M Pantaleo, Sergio M Camporeale, Christos N Markides, Giacomo Scarascia, Mugnozza, Nilay Shah: 'Energy performance and thermo-economic assessment of a microturbine-based dual-fuel gasbiomass trigeneration system', Energy Procedia, 2017,105,764-772.

52. Joaquín Navarro-Esbrí, Fracisco moles, Bernardo Peris, Adrian Mota- Babiloni, Jose Pascual Marti, Robertos Collado, Manuel Gonzalez:'Combined cold, heat and power system, based on an organic Rankine cycle, using biomass as renewable heat source for energy saving and emissions reduction in a supermarket', Energy Procedia, 2017, 129, 652-659.

53. Bahra Saadatfara, Reza Fakhrai, Torsten Franssona: 'Exergo-environmental analysis of nano fluid ORC lowgrade', Energy Procedia, 2014, 61, 1879-1882.

54. M. Mortazaei, M.Rahimi:'A comparison between two methods of generating power, heat and refrigeration via biomass based SOFC: A thermodynamic and environmental analysis', Energy Conversion and Management, 2016, 126, 132-141. 